\title{
12. Social justice goes hand in hand with environmental campaigns - and not just in Africa
}

\author{
Phyllis Omido
}

My experience shows that climate and environmental campaigns are more effective if they are linked to issues of social justice. Without that, many communities feel the issues are too distant.

I used to work in a battery recycling smelter that poisoned the neighbouring community. I didn't realize at first. I was working in the company office. I started to grow concerned in 2010 when my baby son fell ill. Blood tests showed the amount of lead in his blood was 35 times above the World Health Organization's level of concern. I suspected I had passed this on to him through my breast milk, which meant that I was contaminated and so, probably, were others who worked at the smelter or lived nearby. I arranged for three more children to be tested, all of whom proved to have tainted blood. When I talked to local people, they told me about unusually high numbers of miscarriages and respiratory disease. This started a campaign that rallied thousands of people and led to death threats against me, but it is proving effective and there are lessons for others.

Strategies to combat climate change and protect the environment vary from place to place depending on ecosystems and the ways of life of the indigenous communities in each area. In my hometown of Mombasa, we began by mobilizing the local community through demonstrations and public picketing in order to get the state to act. I wrote letters to the National Environment Management Authority and the public health authorities. The aim was to remove the source of lead exposure for the 3000 Owino Uhuru community members. This meant either relocating or shutting down the smelter that was the source of water and air contamination.

Our strategy was permissible by law but very dangerous. Between 2016 and 2018 I received numerous threats both at gunpoint and via text messages. Several times I had to go into hiding. The powerful interests behind the smelter also got the police on their side. This led to my arrest alongside 16 community members. I was charged with inciting violence and illegal gathering. The 
one-year trial appeared designed to silence us. We had to devote so much energy to secure our freedom. We were worried about the legal costs and the possibility of prison terms of up to 15 years. All manner of dirty tricks were used against us. At one stage, our lawyers were contracted by the smelter and they left us in court without legal representation. Luckily, we had contacts in Lawyers Without Borders, which was working with the East Africa Law Society. They provided a pro bono lawyer who secured our acquittal in November 2018. Meanwhile the smelting corporation - which was free from our interference during this period - continued to spew hazardous waste into the community.

I had already decided to rethink our strategy. We went on the counterattack with media advocacy and litigation coupled with civil society activism to challenge violations of environmental management by the company and the state. We fought on the basis that indigenous and marginalized groups in Kenya should have as much right to a clean environment as anybody else. Foreign non-governmental organizations (NGOs), including Front Line Defenders and Human Rights Watch, provided advice and media support. Our work gained international recognition when I was awarded the Goldman Environmental Prize (a co-winner in 2015 with Honduran environmental activist Berta Cáceres, who was later murdered for her activism).

Initially, the Kenyan authorities refused to close the plant. I went over their heads by appealing to the East Africa Community. This regional body banned lead recycling in Kenya, forcing the closure of more than a dozen smelters, including the one at Owino Uhuru.

We tried to use the media as a tool for environmental justice by reaching out to journalists and providing them with information to understand what was happening. This was very important to counter the negative publicity put out by bloggers who were paid to mislead the public. This strategy proved effective in pushing our local campaign to a national and international level. The community received visits by the Senate and Congress. We followed up with petitions to Parliament that led to two key reports by committees in the Upper and Lower Houses. Those studies made people more willing to take our concerns seriously. A detailed medical investigation was carried out under the auspices of the Ministry of Health, which shows the myriad of negative health and environmental impacts in the community that were linked to the smelter.

These reports were an excellent basis from which to prove our case in a class action litigation suit. The combination of media and legal outreach helped us to win in the court of public opinion and prompted state actors to engage with our situation, which had previously been ignored. As a result, we have forced the closure of the plant and are now campaigning for compensation for the victims and a clean-up of the community. 
We want to go further still. We have launched a major constitutional case on the right to a clean healthy sustainable environment, which also has a strong human rights focus. This project has led to collaborations with wider civil society groups to promote environmental rights in Kenya. Our campaigns have also enabled us to penetrate the related processes and systems of government. Our goal is to hold the authorities accountable so that all citizens are guaranteed a healthy environment.

For us, the environment and human rights go hand in hand. We mobilize resources (funds and action) on both. Until now, very few campaigns have been focused on environmental impunity. Too many people think the environment is just about conservation of wildlife or natural parks, but it should be about helping communities to achieve justice. Environmental destruction takes place when powerful people feel they can benefit from impunity. To address this, we need access to information, public participation and to justice.

It is not enough to argue the case for the environment or the climate on the grounds of conservation or science alone. In many communities, that is too vague. Far more effective and important is to demonstrate that it is a matter of justice and equality. 